International Journal of Linguistics, Literature and Culture
Available online at https://sloap.org/journals/index.php/ijllc/
Vol. 7, No. 1, January 2021, pages: 32-44
ISSN: 2455-8028
https://doi.org/10.21744/ijllc.v7n1.1115

\title{
Image of Women in Novels by Okky Madasary
}

Helmi Setiawan ${ }^{\text {a }}$ Anwar Efendi ${ }^{\text {b }}$

Article history:

Submitted: 27 November 2020

Revised: 18 December 2020

Accepted: 09 January 2021

\section{Keywords:}

domestic role; physical form; psychic form; public role; women's image;

\begin{abstract}
This research is descriptive qualitative research using the feminist literary criticism approach. The subject of this research are three novels by Okky Madasari which are titled: 1) Maryam, 2) 86, and 3) Entrok. The technique of data collecting used in this research is to study the library read the note, conducted by reading carefully and repeated thoroughly and classifying the data obtained based on women's image. Analyzing data in this research use the descriptive qualitative method. The research finding in the form of physical women's image, the image of women's psychic and the role of women consisting of domestic and public areas. Domestic roles include as a child, wife, and mother. The role of women in the public domain consists of the educator, economic, and social movement sectors.
\end{abstract}

International journal of linguistics, literature and culture (C) 2021. This is an open access article under the CC BY-NC-ND license (https://creativecommons.org/licenses/by-nc-nd/4.0/).

\section{Corresponding author:}

Helmi Setiawan,

Study Program of Indonesian Language and Literature Education, Postgraduate Program,

Universitas Negeri Yogyakarta, Indonesia.

Email address: helmisetiawan.2017@student.uny.ac.id

\footnotetext{
a Study Program of Indonesian Language and Literature Education, Postgraduate Program, Universitas Negeri Yogyakarta, Indonesia

b Study Program of Indonesian Language and Literature Education, Postgraduate Program, Universitas Negeri Yogyakarta, Indonesia
} 


\section{Introduction}

The traditional view of society considers that women are related to behavior and work relating to housework. This case is explained by Brunetta (1989), revealing that society's expectation toward women is to be wives and mothers, this view is embraced by the aged and adhered to tradition. Sadli (2010), states that the inability of distinguishing the nature and learning outcomes of women leads to role restrictions. Based on the principle of Abdulah (2003), revealed that women are categorized as "second class citizens" who are not taken into account and whose role placement is in a domestic environment while men are in a public environment. Such conditions can change the mindset of society universally so that it follows traditional views regarding the position of women as well as the image of women in the social environment.

Based on these facts, the novel by Okky Madasari seeks to provide a new perspective and picture of women's position and image through literary work so that people easily understand the condition and structure of women's image in the social environment. According to Ambarwati (2009), states the problem faced by women is the difficulty of determining attitudes in finding their identity because it is considered against some people that still adhere to patriarchal culture. The phenomenon of working women shows that women are building a new identity as workers not only as wives or mothers (Abdulah, 2003). In line with the case, Sadli (2010), states that the development of self-potential by women is committed to evaluating themselves, be independent, be responsible for choices towards themselves and others.

Reviewing a novel is certainly inseparable from the author. As stated previously that the author is part of society, the creation of works has its motives. This research tries to look at the image of women in novels by Okky Madasari. Okky Madasari's works present many criticisms of the limitations and discrimination of women in obtaining human rights occurring in society. Another problem also raised by Okky Madasari is corruption often occurring in government agencies and the struggle of minority groups in seeking justice, so that her novels are widely used as material for scientific and non-scientific studies. Okky Madasari also received the award in the form of The Equator Literary Award 2012 through her novel Maryam in the prose category at the age of 28 and became the youngest to win this award. Okky Madasari has many international achievements such as, in 2015 invited by the Austrian government as a speaker in The Islam and Women's Contemporary Literature, in 2017 invited as speaker of the Literature Festival in Germany, 2017 was chosen by the American government, and in 2019 was nominated at Southeast Asia's Women of the Future Awards.

The published works of Okky Madasari are, Entrok, 86, Maryam, Pasung Jiwa (translated in English, German, and Egyptian Arabic), The Last Crowd, The Last Surviving and Perishing Slowly, Eyes in the Land of Melus, Eyes and Secrets of Gapi Island, and Eyes and Sea Men. Based on the 9 novels, the object of research is novels titled Entrok, 86, and Maryam. The selection of these three novels from other novels is considered to fulfill the criteria in reviewing the image of women. The main characters in the three novels Entrok, Maryam, and 86 are women, so the entirety of the story is dominated by women. Based on this case, the novel is assumed to be feminist, so this research uses the study of feminist literary criticism. The study with feminist criticism in this study aims to look at the form of female imagery. The female characters in the novels Entrok and 86 have the uniqueness of a female character as a wife told as the main breadwinner compared to the husband. Entrok and Maryam's novels reflect women in the face of discrimination in the name of religion.

\section{Literature review}

Feminism

The thought stream of the feminism movement developed in various traditions, such as: liberal feminism, radical, socialist, Marxist, postmodern, ecofeminism (Tong, 2010). Each of these traditions or feminism movement has its ideology and background in the establishment. In all these diverse feminist movements, it generally departs from the realization that women are in a low position, oppressed, exploited, and there must be an effort to end this. Feminism is a movement based on assumptions and awareness that women are being oppressed and trying to end it, (Fakih, 2008). Hannam (2007), defines three important characteristics of feminism, 1) awareness of the power imbalance between men and women, 2) the belief that the condition can be changed because the view is a social construction, 3) an emphasis on female autonomy. Another case with Mills (2001), opinion stating that feminists not only perceive women as opposed to male domination but attempt to find ways to gain power for manifestations of themselves in everyday life. To implement this case, Andre Dworkin (Ruthven, 1990), reveals that we must destroy all the roots

Setiawan, H., \& Efendi, A. (2021). Image of women in Novels by Okky Madasary. International Journal of Linguistics, Literature and Culture, 7(1), 32-44. https://doi.org/10.21744/ijllc.v7n1.1115 
defining women as victims. Feminists are also a form of resistance to violence committed structurally as well as directly against women (Zalewski \& Runyan, 2013).

\section{Feminist literary criticism}

Literary criticism is a literary study focusing on judgment (Yamin \& Sinkovics, 2006). In line with Pradopo (1984), that literary criticism gives marking as good or bad literary works by critics. Endraswara (2013), states that there are two important points for criticism in humanist literary works, i.e. (1) improving the quality of literary works from times written by the author, (2) maintaining the existence of the author of his work. Literary criticism has its stages in conducting critique activities. Moreover, literary criticism is a scientific study having systematic levels in its application. Wiyatmi (2012), expresses three stages of literary criticism, (1) interpretation (interpretation) i.e. interpreting literary works by analyzing, paraphrasing, and commentary, (2) analysis (deciphering) i.e. analyzing the building elements to understand literary works, (3) assessment (evaluation) i.e. determining the value of literary works objectively based on the data in the work. Literary criticism is not an assessment generating criticism of literary works, but rather gives an objective assessment based on the data in the literary work as evidence.

Feminist literary criticism is a literary discipline based on feminist understanding focusing on the study of gender equality and the existence of female writers (Wiyatmi, 2017). Showalter further divides distinguished feminist literary criticism into two, (1) feminist literary critiques perceiving women as readers or the women as a reader examining the image, stereotypes, and literary history shaped by men, (2) feminist literary critics perceiving women as writers (gynocritics) (Wiyatmi, 2012). Another opinion proposed by Newton is that feminist literary criticism assesses the extent to which authors and texts reconciled with feminist ideology as feminist political goals have two focuses of study, 1) feminist critics use an image of women's studies in perceiving characters represented in literature, 2) the women's as writer using gynocritic concepts focusing the author as the focus of his studies (Newton, 1993). The meaning of women as readers is the consciousness of the reader understands there is something important in gender differences (Sugihastuti, 2005). The intended awareness in this discussion is there are differences in status and role in gender caused by patriarchal ideology assuming full power exists in men formed by culture and social construction. Patriarchal ideology gives and divides roles to be lived by men and women where positions of dominance are in male and subordinate positions in women (Buberwa, 2016; Kotthoff, 2000; Dittmar et al., 1996; Tiggemann \& Zaccardo, 2015).

Feminist literary critics use gender concepts as the basis of analysis (Sugihastuti, 2005). These concepts include 1) gender differences, such as differences in social attributes, characteristics, behaviors, appearance, how to dress, expectations, roles, and so on, formulated for individuals according to birth provisions, 2) gender gaps, i.e. differences in politics, voting, and behaving between men and women, 3) genderization, i.e. concept allocation to place gender at the center of attention of self-identity and views from and towards others, 4) gender identity, i.e. the description of the person concerned, the emergence of behavioral differences according to biological characteristics, 5) gender role, namely the role of women or men applied in real-time.

\section{Image of women}

Image is an image of the mind which is an effect in the mind resembling (the image) generated by our capture of the objects noticed by the eyes, the nerves of vision, and the regions of the brain relating or concerning (Pradopo, 2002). While Wolman (Roeckelein, 2004), says the image is a mental or psychiatric copy derived from memories based on experience. It is similar to Burhan (2013), that imagery is an overview of sensory experiences resurrected by words. While according to Hastuti \& Sastriyani (2007), the image is a description that can point to something real or represent something unreal. Imagery can display the connection of thoughts and emotions in an instant and is a merging of ideas.

Fakih (2008), reveals women have gentle, beautiful, emotional, and maternal nature. The statement provides a view of the depiction of women physically and mentally. Nancy \& Vuren (1990), say women are portrayed as an assistant of men's work both in a family and social environment. The phenomenon is termed as an image of a woman, female is depicted at the will of men (Ruthven, 1990). Based on that case, the image of women is the view or ideas about women, how their position and role in society, and their potential in the middle of male power (Hastuti \& Sastriyani, 2007).

Based on the description, the image of women can be divided into two i.e. self-image and social. First, women's self-image includes the physical appearance of the outside of the form in the female self which is visible in real life, 
and psychic in the form of psychiatry in women. Jalaluddin (2017), revealed that psychology, in general, learns the mind (cognition), emotion (emotion), and desire (conation) which are symptoms of human psychiatry. Emotion or feeling is a psychological symptom that arguably dominates in daily life. Emotion is all forms of high-intensity psychiatric experience (Cabanac, 2002). Second, social imagery includes position, role, position in family, and environment. In social life, the image of women is the role of women in families shaped by tradition and culture.

\title{
The role of women
}

The era of modernization is the development of society from traditional to modern (Muthe, 2007). The industry influences women's participation in the world of work so that it contributes to economic development (Wibowo, 2011). Ramadani (2016) states that women work not only to meet economic needs but to be recognized by society. Women entering the public environment are known as career women. Lestari (2016), reveals that the role of women in the family is divided into three, 1) role as a child i.e. obeying and making parents happy, 2) the role as a wife is to serve and support the husband in all fields, 3) motherhood that is fostering and building the character of the child. Based on this exposure, it can be concluded that women's roles are divided into two. First, the role of women in the family is roles including as wife, mother, and child. Second, the role of women in the public as workers, a career in fulfilling needs or forms of self-existence.

\section{Materials and Methods}

The technique of data collecting used in this research is to study the library read the note, conducted by reading carefully and repeated thoroughly and classifying the data obtained based on women's image. Analyzing data in this research uses the descriptive qualitative method.

\section{Results and Discussions}

Based on research findings conducted toward novels Maryam, Entrok, and 86 by Okky Madasari analyzing the form of women's image physically, physically, and socially, formal and non-formal education, as well their role in family and society. The following are the result of analysis and interpretation covering the form of an image, education, and women's role.

\section{Physical Imagery}

The form of physical imagery found in the research of novels by Okky Madasari in the form of appearance and physical characteristics (Frank et al., 2005). The physical image of appearance is reflected in how important appearance is for women, while the physical characteristics explain the condition of the female biological body. The explanation is as follows.

\begin{abstract}
Arimbi sells his mobile phone which only sells 300,000. Then she bought a new phone for 1.5 million. People say his new phone is sophisticated, but Arimbi doesn't really understand. She only cares about the model. Pretty in red. The screen is wide and coloured. When it sounds, the sound is melodious, it can even be replaced with a song. More importantly for Arimbi, she has nothing to be ashamed of when she exchanges phone numbers with those lawyers. Arimbi also buys new shoes and bags of the same colour. She mimics ms. Danti's way of dressing up that always wears matching bags and shoes (86, 107-108: 2017).
\end{abstract}

The excerpt shows the appearance is regarded as something important to women. A good and beautiful appearance to be seen can influence yourself and others in a social environment. These influences are feelings of pleasure or increased confidence, as well as a judgment from others. Ratnasari (2017), suggests that dressing has three functions consisting of biological, psychological, and social aspects. The biological aspect leads to body Armor. Psychological aspects as a tool to increase confidence, trust, and provide comfort. The social aspect is related to the condition of the social state of society, such as in closed-dress religions to cover the genitals or to customs or government agencies as

Setiawan, H., \& Efendi, A. (2021). Image of women in Novels by Okky Madasary. International Journal of Linguistics, Literature and Culture, 7(1), 32-44. https://doi.org/10.21744/ijllc.v7n1.1115 
a form of identity, and as a nonverbal communication tool that provides information or reflects the circumstances or personality of a person.

Maryam's face, which used to be ripe, is now shiny white, the result of a monthly treatment at a beauty clinic. Her hair that used to be long until the back is now shoulder-length with reddish paint (Maryam, 49: 2017).

The excerpt above describes a deliberate discoloration of the skin. This is performed by women aiming to achieve the predicate or beautiful size which is the common standard that society embraces. In this modern era, the size of beauty in women embraced by most of society conflates to a similar understanding, generally white and slim-bodied. This is a result of the influence of movies or advertisements through television or the internet.

Ideally, the beauty of women in society is understood according to the size imaged by the thing, so that initially the beauty of each community group differently leads to the idea. Not a few women do the treatment to make their skin white, because it seems to be a condition to be said to be beautiful. Aprilia (2013), suggests that the beautiful ideology for women becoming aware in society as a result of the influence of advertising media in the form of having a slim body, white skin, straight black hair, following the trend in dressing, and so on.

Arimbi doesn't have to wait too long to get kopaja bus to work. And as in normal days, there has never been an empty seat in hours like this. People were standing crammed. Each part of the body will clash with other people's body parts. The women have their bags in their chests. Protect luggage from pickpockets, while protecting their chests from contact with people's bodies (86, 22: 2017).

Based on the excerpt above, women are regarded as beings providing sexual gratification so that it puts women always as victims of sexual harassment, so women should always be vigilant and look after themselves even in public areas. This case illustrates that men have always had power over women in domestic and public areas. In society, women have begun to have freedom of existence, but still, the view as a missing sex object causes women to be harassed, seduced, and others (Jutitha, 2015; Anike et al., 2017).

\section{Physics imagery}

The form of female psychic imagery in novels Maryam, Entrok and 86 by Okky Madasary is described variously in the form of independent, weak, intelligent, sad, self-esteem, and social spirit. The discussion is as follows.

Eight years ago, shortly after Maryam started working at the bank, the two met in a meeting. Twenty-four years of Maryam's age at the time. Just moved to Jakarta after graduating from college in Surabaya. New enjoyed having his own income, which amounted to the most than her classmates, two million rupiah. Having fun shopping for new clothes, polishing her face every morning, going to the salon once a month. Having her own income makes her less dependent on her parents anymore (Maryam, 2012: 16).

The excerpt describes women's independence in fulfilling the needs of all lives by working. The work done by these female figures demonstrates the potential and ability of women to play an independent role in the public domain which is considered a male area of power Earned income can fulfill the needs of life even more. This case indicates emotionally that women's self-reliance leads to self-happiness and the ability to build relationships with others naturally without dependency. Women are in the spotlight when it comes to self-reliance. Indeed, it has not eliminated the view of women as an economically dependent figure. The figure of women as weak creatures in Okky Madasari's novels is shown with surrender and inability to resist so that she accepts any form of injustice or discrimination against her. As for the discussion as follows

His father spoke in a higher tone. He asked Her to come home. "There are lot of good men in the village!" he said. "Those who are educated and raised in the same way will appreciate and love better than the outsiders who always feel the most right." (Maryam, 17: 2017).

The excerpt shows a forced marriage experienced by a woman. Women are portrayed as having no right to determine a partner or husband, so women cannot freely come forward and live life as their will. The right is owned by parents, especially fathers becoming the head of the family. It shows how weak women's positions are and the power of men in a family environment. However, it does not mean that the matchmaking is not good, as long as it is done with the consent of the parties who are in the marriage without any element of coercion or pressure from the other party. 
Women are restricted and seem to have no power over themselves as if they belong to another party. Little (1987), states that married women are considered to belong to their husbands if not yet the property of fathers and brothers.

An intellectual human being is a human having the nature of thinking and broad-sightedness in achieving or seeking the truth. Women as a figure having intellectuals in novels by Okky Madasari are reflected by Marni in Entrok's novels as follows.

I put the roof down, and I took it all out. "What do you want to buy, Dear?" asked her mother, who was sitting in front of the wasp. "Want to make a basket, Mom. Make a trade and then sell it again. It's like aunty Dimah." "Oh, dear, aunty Dimah is indeed a trading talent. The sell-out basket continues".

"I can do it too, Mom. Just a little bit". (Entrok, 42: 2017)

The excerpt shows women's intelligence in seeing opportunities and utilizing them to advance the economy of life. Women as intelligent figures understand the actions that must be taken along with clear goals to achieve a better future. Intelligence is also reflected in the consciousness of various challenges and ready to face and accept the consequences. Furthermore, it is the sadness of women that is represented through tears or crying.

He cried. Ananta didn't say anything. Only his right hand didn't stop moving, up and down his wife's back. "what pain does mother feel??" asked Arimbi as she sobbed. "I'm not clear either. That's going to be surgery. Arimbi's body vibrates hearing the word operation (86, 2017: 188).

The grief experienced by these figures is due to the state of self-concern and caused by others in the form of threats and knowing his parents are sick. Sadness is not a negative or bad feeling, but rather a natural response of the soul to something unpleasant. The expression of crying because of feelings of sadness is closely related to women. This is caused by the woman's sensitivity is greater than man relying on rational reason.

Society's view toward women crying is considered natural or ordinary because a weak and callous image is attached to them, whereas when a man cries it is considered weak or whiny. However, it does not mean that men cannot cry but rather it has been a mindset in the society. This is due to the difference in imagery inherent in both men and women. Also, this situation is evidenced by Deng et al. (2016), in their study on gender differences in emotional responses found that regarding feelings of sadness, women expressed being at a higher level of arousal or emotional attitude than men, but there was no gender difference in emotional experience.

On the eighth day, those people didn't come anymore. This house feels hollow. There was an odd feeling when I left for the market with Ratno. It's like something strange and unusual. But I don't know what. With all efforts I tried to dampen those feelings. I assure that I have to keep working, keep moving on. Don't let Teja's death make me destitute, to be a lost man of no self-esteem. Let the dead rest in the realm there. I'll send you flowers and roast the tumpeng on each imprint. The living must keep working. That's the only thing I can do to keep dying honourably. Did not die as people having no money (Entrok, 174: 2016).

The excerpt indicates that there is self-esteem in the female soul held as a view of life. The character realizes that she is considered a weak being after her husband's death and struggles to fight the situation. The belief that a living man must keep trying and working to maintain her honor and dignity. The concept of self-esteem in a person arises due to discrimination or inequality. In a society that is still steeped in a patriarchal culture, being a widow is not something easy. Women have to face various stereotypes such as flirts or teasers which is commonly associated with economics is an inherent trait in widowhood. Therefore, Marni's self-esteem is formed as a foundation to act in countering these stereotypes.

Unfortunately, there is no female worker here, no matter how much I want to hire them with money as big as male labour. The wages are the same, not smaller just because she's female, more or less just being upsized with three. But no woman has cut down sugar cane. Sugar cane is only a ration for male laborers. The female labour part is just plant beans. But try asking the women how much they earn. At least three hundred a day. Unfortunately, I don't grow rice or beans. If Gods allows, may my sustenance be launched, I have money to buy more land that I will plant rice and beans. I will hire those women and I will pay them no less than their husbands (Entrok, 2016: 103).

The excerpt shows women's concern for other women. Marni's character realizes that women have always been the party of the disadvantaged. This is demonstrated by the difference in the type of work and the gap in wage stagnation

Setiawan, H., \& Efendi, A. (2021). Image of women in Novels by Okky Madasary. International Journal of Linguistics, Literature and Culture, 7(1), 32-44. https://doi.org/10.21744/ijllc.v7n1.1115 
between men and women. Departing from the condition comes moral awareness in Marni as a social being to help others. The excerpt also shows how powerful men are in the employment sector. Men are always on the main and important line compared to women.

Based on these findings, the form of female imagery is regarded in terms of physical and psychic, in terms of physical image or body of women is formed by social construction that boils down to the needs or satisfaction of men. In the psychic aspect of female imagery are a dynamic figure showing her intellectual potential, selfindependence as a woman that is not bound by any party, and resistance to discrimination against her. However, both aspects of the imagery have similarities that place women in positions on the disadvantaged and weak side. It shows how dominant the male side is towards women in the social order of life

\section{The role of women}

Women's involvement in family and public environments has a different pattern. The intended involvement in the role taken in living life. The role of women in the family has been inherent since they have been birth, while the role in the public domain is a new identity as a creature having the same thing as a male.

\section{Domestic role}

Based on the results of the research, the role of women found in novels Maryam, Entrok and 86 by Okky Madasari consists of several aspects such as role as children, wife, and mother. The role of women as children in the family was found to have no such difference in men. Children exist or are born in the world because of their parents. A child in his growth is cared for and educated with love and compassion. So that as a child, they should obey and obedient the parents. In novels by Okky Madasari, the role of women as children to parents is depicted with service and a symbol of family pride, as in the following quotations.

There is not a single thing that requires returning to Jakarta, working to earn a salary as usual. All that occasionally comes up is the unwillingness to abandon the hard-earned achievements she gets. Status, position, pride and usefulness, and of course a feeling of security over the monthly income guarantee. But that sense disappeared instantly as soon as she came face to face with her parents and sister. Finally, the choice slowly hardened, hardening in a determination. Maryam chose to let go of everything. Making Jakarta and everything there as part of the past need not be repeated (Maryam, 2017: 134)

The first excerpt describes the child's service to the parents. Children always have to obey despite having complete control over themselves. The obedience reflected by the female character in the form of parents is made a priority in life, even at the expense of all achievements. As a child makes parenting a priority in life because of its influential role in the development and growth of itself and as an intermediary of success is the participation of parents. Therefore, being obedient and respectful to parents is the children's need and happiness is a requirement. The image of the woman is reflected by the character that as a child she has an awareness that family is the main one, so being devoted and obedient to parents for their happiness is an obligation to do. The role of women as children is a symbol of parental pride, as in the following excerpt.

This is the beginning of a higher degree for a farming family that never knew a single letter. Arimbi was the beginning of that change. The descendants of this family will no longer take care of the land, working in dirtfilled clothes every day. Through Arimbi, his family will enter a new class. An honourable group of learned people. People working in clean clothes, fine-handed without protruding muscles, clean skinned as they continue to be indoors. Arimbi became an office person. No longer as farmer like his parents (86, 2011: 19).

The excerpt describes that as a girl, she can be a symbol of family pride as well as a man. Being a woman that can occupy the position is obtained by women through her education and intelligence. This is in contrast with men getting such recognition from they have been birth. In society, it is still really thick the assumption that boys are greater than girls so it automatically becomes a representative of the family and continues the lineage, whereas girls will only be wives. In certain community traditions, boys are symbols in maintaining clan lineage. Female figures reflect that men and women have the same abilities and degrees as children in the family.

Life in the household all has its role, both husband, wife, as well child. All of that has to be a leader so that the roles run properly and regularly. It is common that men are leaders in the family, so a wife obeys and obedient to the husband. Here is the role of the woman as a wife found. 
Arimbi knows what Ananta doesn't have: money. His salary is always spent on gasoline, eating at the office, and sending money to the village. Ananta pays the rent on the room, and that means Ananta's money won't be enough until the payday date. Arimbi then took the lives of both of them. Without having To Ananta say, "Borrow money," like when they were still dating. They already know each other. After all, for Arimbi, there's no more of my money or your money. It is our money. To live and their happiness. (86, 2017: 136)

In the followed days, the child became the only thing they wanted. All afternoon at work, Maryam asked her friends how to get pregnant immediately. Maryam ate all the foods her friends mentioned: sprouts, honey, and milk that is special to those who already had babies and breastfeeding. (Maryam, 117-118:2017)

The first excerpt shows the role of the wife in helping and supporting the husband in terms of household finances. It is of course committed based on the consent of the husband. The husband-and-wife relationships shown by the figures have no separate status, but rather mutually helpful and complementary relationships. The woman in the excerpt is described as a devout wife to the husband and has a high sense of responsibility for the family. Wives are generally in charge of home affairs, while it is the husband working for the family. It does not mean that the wife is out of hand on the affair because success in building a household is a shared obligation. Husband and wife relationships in the family are not entwined in a hierarchy but rather functional relationships that mean complementing each other or cooperating (Zuhran, 2013).

The second excerpt above shows that when a household has no children, women are considered as the cause. Having a child for a woman is not only to make happiness but rather as a mandatory duty and proof that she is a complete woman. This view has been cultured and hereditary, giving rise to stereotypes that result in women being used as tools to produce descendants.

In the view of society, when a family has no children, women are considered as the cause. Infertility can also occur in men. Women being unable to give descendant will be considered fail to be female and will not often be labeled "barren" which is a form of social punishment. Women who cannot give a descendant can threaten their position as a wife in the household because it is not uncommon for women to be cheerful on those grounds. The state of reality in society found by Matondang (2014), that one of the causes of divorce in the household is not having children. This situation caused discord and quarrel because it accused each other that one of the parties was causing it (barren). In this case, it is women targeted and harmed for not being able to give children.

The role of women in the domestic sector is the role of women as mothers that close to domestic work. Domestic work, women dominate more than men making a living outdoors. One of the main roles for women is educating children. The mother is the closest person and the first teacher for the child because in the early formation of the character of the child is heavily influenced by family education, especially the mother. Before entering the community, children first get all the necessary education from family to be ready and easy to socialize (Ristianah, 2015). The role of a mother is reflected in the novels by Okky Madasari as follows.

For twenty years I've always heard mom tell me about the difficulty of making money. About the story of old times, when she walked to Ngranget Market. About his destitute life, she could not buy bra. Mother always repeats the story along with the desire for her son to go to school, let him be an employee. She's going to spend any money to get me to school. It doesn't matter if she earns hard. (Entrok, 53-54: 2016)

This excerpt describes the role of women as a mother in educating their children. The female character gives a reflection of educating through the story of her life experience so that her son is motivated to get a better life in the future. Every parent wants their child to have a better life than him or her. Lestari (2011: 55) states how important the role of women in the family which is one of them is to the child. Women in the household have a role in shaping the personality and formation of the child's personality. To survive in life, requires a good or effective relationship between the child and the parent. This is caused because parents are the first figures and knowledge of the outside world.

\section{Public role}

The phenomenon of women being in the public sector is an attempt of women out of male domination. Moreover, the public sector is a place to find a new identity for herself to pursue a career. The role of women in the public sector in novel 86, Maryam and Entrok shows women's progress in thinking and acting. The roles of women are found in various sectors in the form of education, economics, and social movements. The discussion is as follows. The role of

Setiawan, H., \& Efendi, A. (2021). Image of women in Novels by Okky Madasary. International Journal of Linguistics, Literature and Culture, 7(1), 32-44. 
women in education shows progress and high intelligence. Women's involvement in education has not only taken part in formalities but has crept to a higher place as an educator. This indicates that the opportunities and involvement of women in education are deepening. Here is the involvement of women in education as teachers shown by rahayu characters in the novel Entrok.

The four of us came to train the teachers in this area. People who live with sincerity, divide the knowledge that they have into people who do not understand at all (Entrok, 139: 2016).

The excerpt reflects the role of women as teachers. The teacher is imaged as a smart and educated person because they have more knowledge to teach others. This shows that women in education are not only in the form of formality participation but have played an active role in efforts to educate society. The role reflected by rahayu figure shows that women have the same role as men in education.

One of the women's roles in the public environment is in economics such as work. Working in the public sector can be realized with various kinds such as trading in the market or employees of government agencies. In doing work in the public sector becoming a realm outside the habits of women is influenced by a variety of factors. These factors include, among others, 1) external conditions allowing and attract working women, because they have a lot of free time, 2) economic reasons such as low husband income, 3) psychological reasons, such as pleasure, eliminating saturation at home, and self-existence and 4) social responsibility, such as practicing the knowledge gained from college (Nofianti, 2016).

Women working in the public sector found in this research are as economic as traders, bank employees, and government employees. The role of women in the public sector is undersized by the low household economy causing women to be the main breadwinners in the family and the existence of themselves as women. The discussion is as follows.

I know it is Mom working the most for what she got. Father just help, drive to the market every day, accompany mom to collect debt from one house to another. Father make no difference like labourer in the market that is just waiting for the person who needs to be picked up. Otherwise, he'll just shut up even if he doesn't eat all day. If mother does not go to the market, father do either. If mother does not get any money, we won't eat. Even so, she never vilified her husband. Father has never prosecuted any kind of money. All the advantages of the basket, whether it's the basket of goods or the money basket, are held by Mom. (Entrok, 2016: 74)

The excerpt describes that women can act as the main breadwinners in the family by working as traders. The condition is caused by the low income of the husband in fulfilling the needs of the household, so the wife helps the needs of the family. This case can be proof that women can not only do household-related work, such as cooking, child care, washing, and so on.

These circumstances do not make women (wives) want to be leaders in the family, but still do not forget nature as wives. The excerpts also show that fulfilling the family's need is not entirely in the hands of men. The division of work based on sexual embraced by society is men serving in the public sector while women in the domestic sector are not absolute because it can be changed according to the state of the household. In this excerption, it is also explained that there are cooperation and mutual help between women and men in meeting household needs. Santoso (2020), explains that the basic principle of fulfilling the needs of living in the household is the responsibility of husband and wife. In this case, do it together with the principle of pissed off, cooperation, and partnership without any dominant element on the grounds of social status, resources, or gender.

She rushed to take a shower, worked back. Hide behind computer screens, sink into tables containing numbers, estimate people's wealth, then decide if they can get a loan. The work she has been doing for eight years. Who has given material satisfaction, also introduced to her future husband (Maryam, 2017: 15).

This excerpt describes women working in the public sector as bank employees as self-existence in society. The existence of women in careers is performed to achieve satisfaction and become one way to develop themselves. The figures show that women can work like men as bank employees. The phenomenon of women work in the public sector is not separated from the consequences of modernization in the field of industry and education opening women opportunities to achieve high careers of course supported by the educational background taken. The image of women reflected by the figure that women also have their desires for themselves as well as the ability to actively act 
as their females sing in a society like men. Furthermore, the role of women as government employees, as in the following excerpts.

\begin{abstract}
A week passed, Arimbi is still busy copying some of the files piled up on her desk. There's no new trial schedule yet for her. Judge Dewabrata's verdict on Maemunah's land was completely untouched. She works in the order that Ms. Danti has arranged (86, 2017: 41).
\end{abstract}

The excerpt shows the role of women in government agencies as court clerks. This suggests that the role of women in the public sector is advancing and growing, despite sitting positions as a typist. The role of women as government employees is considered sufficient to represent the government's recognition of the ability and women's education in the public sector.

Social movements arise from awareness and concern for the surrounding environment such as social, political, or economic issues. Social movements can take shape in various actions such as providing assistance, criticism, or protest. One of the main characteristics of social movements is the freedom of expression and voicing opinions. These freedoms are both individual and collective rights, allowing people have the opportunity to convey, seek, receive, and share a wide range of information, who can develop and express their opinions or views in a way that they think is appropriate (Setiawan, 2017). Here is a social movement conducted by women as activists in expressing opinions displayed by rahayu figures in the novel Entrok.

Twenty people took part in the action. Amri and imam took turns shouting through the loudspeaker funnel. We brought various posters asking for the men to be fired. A large photo of Mehong captured by Taufik is displayed in the front row. Photos when he was healthy, when we came for interviews, there were also photos of when he had been longitudinal as a corpse. In front of us, rows of men in uniform were confronted (Entrok, 2016: 160161).

The excerpt shows women's struggle to make up their minds in society as activists through demos. The reflection of women built by these figures is the intellectual and educated way of women fighting injustice. Education advances the way of thinking and acting. From a feminist point of view, the actions shown by rahayu figure reflect that women are free, have their own will, and can play an active role in society.

The freedom of speech or expressing thoughts in public is everyone's right without any exception. This has been regulated by the government in the 1945 Constitution 28E paragraph 3 means anyone in Indonesia has the right to freely union, gather, and issue opinions. In addition to being nationally regulated freedom of speech is also found in article 19 of the UN Charter on Human Rights which essentially states giving freedom to anyone to issue opinions (Setiawan, 2017).

In conveying thoughts and views on a thing in life. Although it is legally regulated and recognized nationally and internationally, the freedoms are not yet fully comprehensive on the layers of society. Women born and living in an environment that clings to patriarchal culture are not affected by these rules. The image of women depicted by the figures in these quotations is a form of resistance to the view, that women have rights and freedoms of their own. It is also a cultural break-in or stigma that harms women.

\title{
4 Conclusion
}

Based on the results and discussion of the image of women in Okky Madasari novels. Here the conclusions appropriate to the purpose of this study.

First, the form of female imagery in terms of physical, female image is formed by social construction that boils down to the needs or ideas idealized by men making women submissive. This causes women to be in a weak position or second-class human beings because of the value system which has been awakened in society. As a result, women are exploited and subjected to sexual harassment. On the psychic side, women are imaged as dynamic figures showing intellectual potential, self-independence as women that are not bound by any party, and against discrimination against her. Both of these cases show a contradiction between the physical image that is constructed in society and the psychic that becomes the identity of women. The psychic image mirrored by women is a form of rejection or negation of the stigma of women that are still attached or still embraced in society.

Second, the role of women in domestic and public sectors. The role of women in the domestic sector shows women as domestic beings that generally look like, devoted to parents, devoted to husbands, educating, and caring

Setiawan, H., \& Efendi, A. (2021). Image of women in Novels by Okky Madasary. International Journal of Linguistics, Literature and Culture, 7(1), 32-44. https://doi.org/10.21744/ijllc.v7n1.1115 
for children. However, their position in the domestic environment of men with women has no difference as the researchers found that women become a symbol of family pride that used to be the predicate of men. Domestic roles becoming tools of discrimination against women constructed by women's traditions and culture have not been completely lost i.e. women are considered to play a full role or responsibility for the existing and not hereditary in the family when in reality the situation can also be caused by men.

In the public sector, the role of women is built by showing an active role in various aspects of the public environment. This involvement demonstrates the ability and intelligence that is possessed in contributing and being a driver in the environment such as in education, economics, and other social activities. Moreover, it is as a form of enlightenment that men and women have the same abilities, opportunities, and rights in various layers of public space. The role of women in the public sector is beneficial for themselves and others. Even women can replace men as the main breadwinners in the family. The public's view of women believing that their existence is more synonymous with the domestic territory is no longer relevant.

\section{Conflict of interest statement}

The authors declared that they have no competing interests.

\section{Statement of authorship}

The authors have a responsibility for the conception and design of the study. The authors have approved the final article.

\section{Acknowledgments}

We are grateful to two anonymous reviewers for their valuable comments on the earlier version of this paper. 


\section{References}

Abdulah, I. (2003). Sangkan Paran Gender. Yogyakarta: Pusat Penelitian Kependudukan UGM.

Ambarwati, A. (2009). Perspektif Feminis Dalam Novel Perempuan Di Titik Nol Terjemah Novel Imra'atun'inda Nuqtah Al-Shifr Karya Nawal El-Sa'dawi Dan Perempuan Berkalung Sorban Karya Abidah ElKhalieqy. Online). http://e-journal. iainpekalongan. ac. id/diakses, 26, 22-31.

Anike, H. O. O., Okafor, C. N., \& Udejinta, N. B. (2017). The role of public enterprises in economic development in Nigeria. International research journal of management, IT and social sciences, 4(2), 179-189.

Aprilia, D. R. (2013). Iklan dan Budaya Popular: Pembentukan Identitas Ideologis Kecantikan Perempuan oleh Iklan (Analisis Semiotika Iklan Cetak WRP Body Shape \& Prolene).

Brunetta, W. R. (1989). Peran Kaum Wanita. Bagaimana menjadi cakap dan seimbang dalam aneka peran, Yogyakarta: Kanisius.

Buberwa, D. (2016). Patriarchy ideology and workload inequality within household. Journal of Human-Social Science, 16(1), 1-9.

Burhan, N. (2013). Teori Pengkajian Fiksi Yogyakarta.

Cabanac, M. (2002). What is emotion?. Behavioural processes, 60(2), 69-83. https://doi.org/10.1016/S03766357(02)00078-5

Deng, Y., Chang, L., Yang, M., Huo, M., \& Zhou, R. (2016). Gender differences in emotional response: Inconsistency between experience and expressivity. PloS one, 11(6), e0158666.

Dittmar, H., Beattie, J., \& Friese, S. (1996). Objects, decision considerations and self-image in men's and women's impulse purchases. Acta psychologica, 93(1-3), 187-206. https://doi.org/10.1016/0001-6918(96)00019-4

Endraswara, S. (2013). Prinsip, Falsafah, dan Penerapan Teori Kritik Sastra. Yogyakarta: Center for Academic Publishing Service CAPS.

Fakih, M. (2008). Analisis gender dan transformasi sosial. Insist Press.

Frank, L. D., Schmid, T. L., Sallis, J. F., Chapman, J., \& Saelens, B. E. (2005). Linking objectively measured physical activity with objectively measured urban form: findings from SMARTRAQ. American journal of preventive medicine, 28(2), 117-125. https://doi.org/10.1016/j.amepre.2004.11.001

Hannam, J. (2007). Feminism: A short history of a big idea. UK: Pearson Educated Limited.

Hastuti, S., \& Sastriyani, S. H. (2007). Glosarium seks dan gender. Yogyakarta: ÇarasvatiBooks.

Jalaluddin, I. (2017). Rural Area Learners' Writing Self-efficacy Development: A Qualitative and Quantitative Approaches. Al-Ta lim Journal, 24(3), 255-265.

Kotthoff, H. (2000). Gender and joking: On the complexities of women's image politics in humorous narratives. Journal of pragmatics, 32(1), 55-80. https://doi.org/10.1016/S0378-2166(99)00031-4

Lestari, D. (2016). Eksistensi Perempuan dalam Keluarga (Kajian Peran Perempuan sebagai Jantung Pendidikan anak). Jurnal Eksistensi Perempuan dalam Keluarga, 260-266.

Little, J. (1987). Gender relations in rural areas: the importance of women's domestic role. Journal of rural studies, 3(4), 335-342. https://doi.org/10.1016/0743-0167(87)90052-0

Madasari, Okky. (2010). Entrok. Jakarta: PT Gramedia Pustaka Utama.

Madasari, Okky. (2011). 86. Jakarta: PT Gramedia Pustaka Utama.

Madasari, Okky. (2012). Maryam. Jakarta: PT Gramedia Pustaka Utama.

Matondang, A. (2014). Faktor-faktor yang mengakibatkan perceraian dalam perkawinan. JPPUMA Jurnal Ilmu Pemerintahan dan Sosial Politik Universitas Medan Area, 2(2), 141-150.

Maulana, Faridh. 2017. Citra Wanita Dalam Novel-Novel Karya Habiburrahman El-Shirazy Tesis Universitas Negeri Yogyakarta, Yogyakarta.

Mills, S. (2001). Discourse: New Critical Idiom. New York: Tylor adn Franciss e-Library.

Munthe, H. M. (2007). Modernisasi dan perubahan sosial masyarakat dalam pembangunan pertanian: suatu tinjauan sosiologis.

Nancy dan Vuren. (1990). Wanita dan Karier Bagaimana Mengenal dan mengatur Karya Terjemahan A.G. Lunandi.

Newton, K. M. (1993). Twentieth-Century literary theory: A Reader. New York: St. Martin's Press.

Nofianti, L. (2016). Perempuan di sektor publik. Marwah: Jurnal Perempuan, Agama dan Jender, 15(1), 51-61.

Pradopo, R. D. (1984). Masalah angkatan dan penulisan sejarah sastra Indonesia. Ditjen Kebudayaan Depdikbud.

Pradopo, R. D. (2002). Kritik sastra Indonesia modern. Gama Media.

Ramadhani, N. (2016). Implikasi peran ganda perempuan dalam kehidupan keluarga dan lingkungan masyarakat. Sosietas, 6(2).

Setiawan, H., \& Efendi, A. (2021). Image of women in Novels by Okky Madasary. International Journal of Linguistics, Literature and Culture, 7(1), 32-44. https://doi.org/10.21744/ijllc.v7n1.1115 
Ratnasari, N. P. (2017). Susan Cooper's Struggle For Equality In Workplace Portrayed In Paul Feig's Spy Movie (Doctoral dissertation, Universitas Brawijaya).

Ristianah, N. (2015). Pendidikan Anak dalam Keluarga. Jurnal Pikir: Jurnal Studi Pendidikan dan Hukum Islam, 1(2), 122-145.

Roeckelein, J. E. (2004). Imagery in psychology: A reference guide. Greenwood Publishing Group.

Ruthven, K. K., \& Ruthven, K. K. (1990). Feminist literary studies: an introduction. Cambridge University Press.

Sadli, S. (2010). Berbeda tetapi setara: pemikiran tentang kajian perempuan. Penerbit Buku Kompas.

Santoso, L. B. (2020). Eksistensi Peran Perempuan Sebagai Kepala Keluaraga (Telaah terhadap Counter Legal DrafKompilasi Hukum Islm dan Qira'ah Mubadalah). Marwah: Jurnal Perempuan, Agama dan Jender, 18(2), 107120.

Setiawan, R. (2017). Kebebasan Ekspresi Individual dalam Pembangunan Manusia Era Digital. In Prosiding Seminar Nasional Pendidikan FKIP (Vol. 1, No. 2).

Sugihastuti, S. (2005). Kritik sastra feminis: Teori dan aplikasinya. Yogyakarta: Pustaka Pelajar.

Tiggemann, M., \& Zaccardo, M. (2015). "Exercise to be fit, not skinny": The effect of fitspiration imagery on women's body image. Body image, 15, 61-67. https://doi.org/10.1016/j.bodyim.2015.06.003

Tong, R. P. (2010). Feminist Thought: Pengantar Paling Komprehensif kepada Arus Utama Pemikiran Feminis, terj. Aquarini Priyatna Prabasmoro. Yogyakarta: Jalasutra.

Wibowo, D. E. (2011). Peran ganda perempuan dan kesetaraan gender. Jurnal Muwazah, 3(1), 356-364.

Wiyatmi, W. (2012). Kritik Karya Feminis Teori dan Aplikasinya dalam Sastra Indonesia.

Wiyatmi. W. (2017). Perempuan dan Bumi Dalam Sastra dari Kritik Sastra Feminis, Ekokritik, Sampai Ekomfeminis. Yogyakarta: Cantrik Pustaka.

Yamin, M., \& Sinkovics, R. R. (2006). Online internationalisation, psychic distance reduction and the virtuality trap. International Business Review, 15(4), 339-360. https://doi.org/10.1016/j.ibusrev.2006.03.002

Zalewski, M., \& Runyan, A. S. (2013). Taking feminist violence seriously in feminist international relations. International Feminist Journal of Politics, 15(3), 293-313.

Zuhrah, F. (2013). Relasi Suami Dan Istri Dalam Keluarga Muslim Menurut Konsep Al-Quran: Analisis Tafsir Maudhuiy. Journal Analytica Islamica, 2(1), 177-192. 